\title{
Plasmid profile of Escherichia coli 0157:H7 from apparently healthy animals
}

\author{
Smith $\mathrm{SI}^{1 *}$, Aboaba $\mathrm{OO}^{2}$, Odeigha $\mathrm{P}^{3}$, Shodipo $\mathrm{K}^{2}$, Adeyeye $\mathrm{JA}^{3}$, Ibrahim $\mathrm{A}^{3}$, Adebiyi $\mathrm{T}^{1}$, \\ Onibokun $\mathrm{H}^{1}$ and Odunukwe $\mathrm{NN}^{1}$ \\ ${ }^{1}$ Molecular Biology and Biotechnology Division, Nigerian Institute of Medical Research, P.M.B. 2013, Yaba, Lagos, \\ Nigeria. \\ ${ }^{2}$ Department of Microbiology, University of Lagos, Nigeria. \\ ${ }^{3}$ Department of Cell Genetics, University of Lagos, Nigeria.
}

Accepted 22 August 2003

One hundred samples from healthy animals were screened for the presence of enterohaemorrhagic Escherichia coli 0157: H7 and 17 were positive for EHEC 0157:H7 after confirmation using serology kits. Antibiotic susceptibility patterns showed the isolates to be highly susceptible to the various antibiotics screened with a few showing multiple antibiotic resistance. The plasmid profiles revealed that $8 / 17(47 \%)$ of the animal isolates harboured detectable plasmids ranging in size from $0.564 \mathrm{~kb}$ to $>23 \mathrm{~kb}$.

Key words: Escherichia coli, EHEC, animals, plasmid profile.

\section{INTRODUCTION}

Infection caused by Escherichia coli 0157:H7 has become a significant public health problem world-wide (Armstrong et al., 1996). The forms of transmission are animal-toperson, waterborne and person to person (Armstrong et al., 1996; Coia, 1998). Cattle faeces has been recognised as the principal reservoir of the microorganism in waterborne and food-borne E. coli 0157:H7 outbreaks and sporadic infections (Armstrong et al., 1996; Coia, 1998). Enterohaemorrhagic E. coli (EHEC) $0157: \mathrm{H} 7$ is the dorminant shiga toxin producing strain that is known to be associated with both outbreak and sporadic cases of human diseases ranging from uncomplicated diarrhoea to haemorrhagic colitis and haemolytic uraemic syndrome (HUS). Their ability to cause severe diseases is related to their capacity to secrete shiga toxins also called verotoxins.

${ }^{\star}$ Corresponding author; E-mail: stellaismith@yahoo.com, Fax: 002341862865 .
The prevalence of EHEC in animals has not been studied in Nigeria to the best of our knowledge. In this report, the commonly consumed animals in Nigeria were investigated for the prevalence of EHEC 0157:H7.

\section{MATERIALS AND METHODS}

Faeces from cattle, pigs, rams and goats observed defaecating were collected from Ventata farms, Gbagada Cattle Ranch, and Ajayi Farms in Lagos State and Pakoto farm in Ifo, Ogun State in universal sterile container and immediately transported to the laboratory for processing and culture. Briefly, $1 \mathrm{~g}$ suspension of faeces was placed in $9 \mathrm{ml}$ of peptone water and vortexed. After which, $0.1 \mathrm{ml}$ of the same buffer was equally spread onto the surface of sorbitol MacConkey agar and incubated for $24 \mathrm{~h}$ at $37^{\circ} \mathrm{C}$.

Non-sorbitol fermenting colonies were picked and characterized using biochemical systems. The sorbitol negative colonies were serologically typed for 0157:H7 antigens by slide agglutination with polyvalent and 
monovalent anti-E. coli $\mathrm{O}$ and $\mathrm{H}$ sera (Biogenetics Diagnostics, Padua, Italy). Haemolytic activity of the isolates were tested by culturing the isolates in $\mathrm{BHI}$ containing $7 \%$ human blood and incubating at $37^{\circ} \mathrm{C}$ for 24 h.

Susceptibility of the organisms to antibiotics was tested by the disk diffusion method on $\mathrm{BHI}$ according to Bauer et al. (1966). The following antibiotics were used: ampicillin, colistin, gentamicin, nitrofurantoin, cotrimoxazole, streptomycin and tetracycline. The method of Birnboim and Doly (1979) was employed for plasmid screening. The DNA were electrophoresed on $0.8 \%$ agarose gel, stained with ethidium bromide, visualized by UV transillumination and photographed. Molecular weights were calculated based on molecular weight standard.

Table 1. Distribution of serologically confirmed $E$. coli isolates and their sources.

\begin{tabular}{|c|c|c|c|}
\hline $\begin{array}{c}\text { Animal } \\
\text { type }\end{array}$ & $\begin{array}{c}\text { No. of } \\
\text { samples }\end{array}$ & $\begin{array}{c}\text { Non-sorbitol } \\
\text { fermenters }\end{array}$ & $\begin{array}{c}\text { Serologically } \\
\text { confirmed }\end{array}$ \\
\hline Cow & 40 & 27 & 7 \\
Ram & 30 & 13 & 2 \\
Pig & 17 & 12 & 5 \\
Goat & 13 & 6 & 3 \\
Total & 100 & 58 & 17 \\
\hline
\end{tabular}

\section{RESULTS AND DISCUSSION}

EHEC 0157:H7 was isolated from $17 \%$ of animals in this study (Table 1). The E. coli isolates showed haemolytic activity on blood agar plates. Our results show that $18 \%$ of the animal isolates showed multiple antibiotic resistance while when tetracycline resistance was taken alone it was $35 \%$ (Table 2). There has been increasing concern of the possible development of resistance to antimicrobial agents in the Enterobacteriaceae, especially $E$. coli as a result of the use of such agents in animal feed (Willis, 2000). This resistance is quite high and it could be as a result of the widespread use of such agent in animal feed in Nigeria. Plasmid profile analyses revealed that there are detectable plasmids in $47 \%$ of the isolates. Plasmids were detected from eight $(47 \%)$ animal isolates, three from cows $(>23.13$ and $4.361 \mathrm{~kb} ; 0.564 \mathrm{~kb})$, one from goat $(>23.13 \mathrm{~kb})$, two from pigs $(>23.13,2.322$ and 2 $\mathrm{kb} ;>23.13 \mathrm{~kb}$. The last two from ram had sizes of $>23.13$ $\mathrm{kb}$ each (Figure 1).

All the isolates had large molecular weight plasmids $>23.130 \mathrm{~kb}$. Large molecular weight plasmids $(90 \mathrm{~kb})$ have commonly been associated with toxigenic strains (Bopp et al., 2003). Further virulence tests on these isolates are required as these animals are commonly
Table 2. Antibiotic susceptibility patterns of the $E$. coli isolates.

\begin{tabular}{|c|c|c|c|c|c|c|c|c|}
\hline \multirow{2}{*}{$\begin{array}{c}\text { Code } \\
\text { no. }\end{array}$} & \multicolumn{8}{|c|}{ Antibiotic susceptibility patterns } \\
\hline & Ap & Col & Gen & $\mathrm{Nal}$ & $\mathrm{Nit}$ & Cot & Str & Tet \\
\hline $\mathrm{P} 1$ & $\mathbf{R}$ & $\mathbf{R}$ & $\mathrm{S}$ & $\mathrm{S}$ & $\mathrm{S}$ & $\mathrm{S}$ & $\mathrm{s}$ & $\mathbf{R}$ \\
\hline P2 & s & $\mathbf{R}$ & $\mathrm{s}$ & s & $\mathrm{s}$ & $\mathrm{s}$ & s & $\mathbf{R}$ \\
\hline P3 & $\mathrm{s}$ & $\mathbf{R}$ & $\mathrm{s}$ & s & $\mathrm{s}$ & S & $\mathbf{R}$ & $\mathrm{s}$ \\
\hline P4 & $\mathrm{s}$ & S & $\mathrm{s}$ & s & $\mathrm{s}$ & S & s & $\mathbf{R}$ \\
\hline G1 & S & S & $\mathrm{s}$ & $\mathrm{s}$ & $\mathrm{s}$ & $\mathbf{R}$ & s & $\mathbf{R}$ \\
\hline G2 & $\mathrm{s}$ & $\mathbf{R}$ & $\mathrm{s}$ & s & $\mathrm{s}$ & S & s & $\mathrm{s}$ \\
\hline P5 & $\mathrm{S}$ & $\mathbf{R}$ & $\mathrm{S}$ & $\mathrm{S}$ & $\mathrm{S}$ & $\mathrm{S}$ & S & $\mathrm{S}$ \\
\hline G3 & S & $\mathbf{R}$ & S & S & $\mathrm{S}$ & S & S & $\mathrm{S}$ \\
\hline R1 & $S$ & $\mathbf{R}$ & $\mathbf{R}$ & $\mathbf{R}$ & $\mathbf{R}$ & $\mathbf{R}$ & $\mathbf{R}$ & $\mathbf{R}$ \\
\hline R2 & S & $\mathbf{R}$ & S & S & $S$ & S & $S$ & $S$ \\
\hline C1 & $\mathbf{R}$ & $\mathbf{R}$ & S & $\mathbf{R}$ & $\mathbf{R}$ & $\mathbf{R}$ & $\mathbf{R}$ & $\mathbf{R}$ \\
\hline C2 & $\mathbf{R}$ & $\mathbf{R}$ & $S$ & $\mathbf{R}$ & $\mathbf{R}$ & $\mathbf{R}$ & $\mathbf{R}$ & $S$ \\
\hline C3 & $\mathbf{R}$ & $S$ & $S$ & $S$ & $S$ & $S$ & $S$ & $S$ \\
\hline C4 & $S$ & $S$ & $S$ & $S$ & $S$ & $S$ & $S$ & $S$ \\
\hline C5 & $S$ & $\mathbf{R}$ & $S$ & $S$ & $S$ & $S$ & $S$ & $S$ \\
\hline C6 & S & $\mathbf{R}$ & S & $S$ & $S$ & $\mathbf{R}$ & $S$ & $S$ \\
\hline C7 & $S$ & $\mathbf{R}$ & $S$ & $S$ & $S$ & $S$ & $S$ & $S$ \\
\hline
\end{tabular}

Ap, ampicillin; Col, colistin; Gen, gentamicin; Nal, nalidixic acid; Nit, nitrofurantoin; Cot, cotrimoxazole; Str, streptomycin; Tet, tetracycline. $\mathrm{R}$, resistant; $\mathrm{S}$, sensitive.

P, pig; G, goat; R, ram; C, cow.

a.

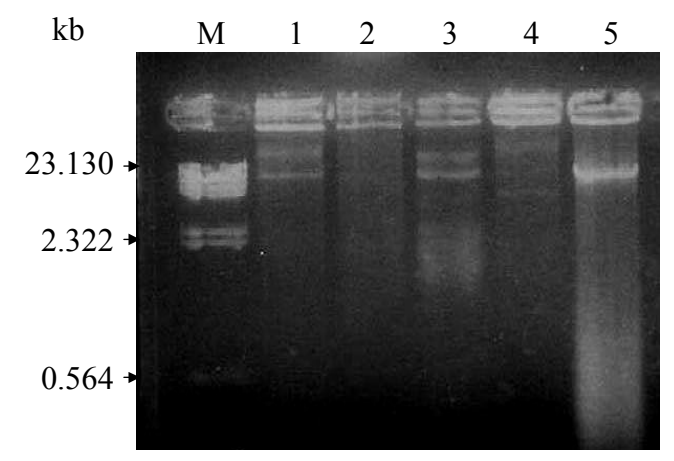

b.

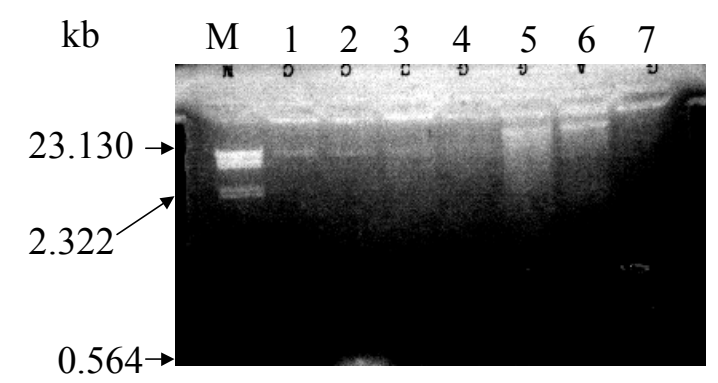

Figure 1. Agarose gel electrophoresis showing plasmid profile of EHEC from the isolates. (a) Lanes: M, molecular weight marker $(\lambda$, Hindlll digest); 1 , ram isolate; 2, pig isolate; 3 , pig isolate; 4 , cow isolate $(>23.13 \mathrm{~kb}) ; 5$, cow isolate $(9.416 \mathrm{~kb})$. (b) Lanes: $M$, molecular weight marker ( $\lambda$, HindllI digest), 1 , cow isolate (no plasmid); 2, cow isolate ( $0.564 \mathrm{~kb}) ; 3$, cow isolate (no plasmid); 4 , goat isolate (no plasmid); 5 , goat isolate $(>23.13 \mathrm{~kb}) ; 6$, ram isolate (>23.13 kb); 7, goat isolate (no plasmid). 
consumed animals in Nigeria. The goat and ram isolates shared the same plasmid size $(>23.13 \mathrm{~kb})$ and were from the same farm, showing that the EHEC isolates may be epidemiologically related. In conclusion, EHEC 0157:H7 strains from animals in Nigeria have shown a high prevalence. These isolates have shown high resistance especially to tetracycline and so farm workers and health workers should greatly consider the health risk to humans associated with using such agents in animal feed. This is due to development of resistance amongst these animals and the possible transfer to humans.

\section{ACKNOWLEDGEMENT}

SIS is grateful to Alexander von Humboldt for the provision of the Gel Cam camera used for taking the pictures in this article.

\section{REFERENCES}

Armstrong GL, Hollingsworth J, Morris JG (1996). Emerging foodborne pathogens: Escherichia coli $0157: \mathrm{H} 7$ as a model of entry of a new pathogen into the food supply of the developed world. Epidemiol. Rev. 18: 29 - 51.
Bauer AW, Kirby WM, Sherris JC, Turck M (1966). Antibiotic susceptibility testing by a standardized single disk method. Am. J. Clin. Pathol. 1966 45:493-496.

Birnboim HC, Doly J (1979). A rapid alkaline extraction procedure for screening recombinant plasmid DNA. Nucleic Acids Res. 7:15131523.

Bopp DJ, Saunders BD, Waring AL, Ackelsberg J, Dumas N, BraunHowland E, Dziewulski D, Wallace BJ, Kelly M, halse T, Musser KA, Smith PF, Morse DL, Limberger RJ. (2003). Detection, Isolation and Molecular subtyping of Escherichia coli 0157:H7 and Campylobacter jejuni associated with a large waterborne outbreak. J. Clin. Microbiol. 41: $174-180$.

Coia JE (1998). Clinical, microbiological and epidemiological aspects of Escherichia coli 0157 infection. FEMS Immunol. Med. Microbiol. 20: 1 - 9.

Willis C (2000). Antibiotics in the food chain: their impact on the consumer. Rev. Med. Microbiol. 11: 153 - 160. 